\title{
A Weibull-PBPK model for assessing risk of arsenic-induced skin lesions in children
}

\author{
Chung-Min Liao ${ }^{a, *}$, Tzu-Ling Lin ${ }^{a}$, Szu-Chieh Chen $^{b}$

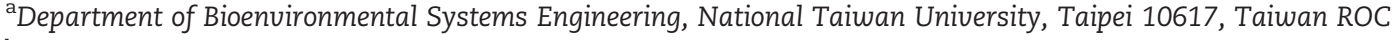 \\ ${ }^{b}$ Department of Public Health, Chung Shan Medical University, Taichung 40242, Taiwan ROC
}

\section{A R T I C L E I N F O}

Article history:

Received 17 July 2007

Received in revised form

6 December 2007

Accepted 10 December 2007

Keywords:

Arsenic exposure

Children

Skin lesions

Methylation capacity

Risk assessment

\begin{abstract}
A B S T R A C T
Chronic arsenic exposure and skin lesions (keratosis and hyperpigmentation) are inextricably linked. This paper was to quantify the children skin lesions risks and to further recommend safe drinking water arsenic standard based on reported arsenic epidemiological data. We linked the Weibull dose-response function and a physiologically based pharmacokinetic (PBPK) model to estimate safe drinking water arsenic concentrations and to perform the risk characterization. We calculated odds ratios (ORs) to assess the relative magnitude of the effect of the arsenic exposure on the likelihood of the prevalence of children skin lesions by calculating proposed Weibull-based prevalence ratios of exposed to control groups associated with the age group-specific PBPK model predicted dimethylarsinite (MMA(III)) levels in urine. Positive relationships between arsenic exposures and cumulative prevalence ratios of skin lesions were found using Weibull dose-response model $\left(r^{2}=0.91-0.96\right)$. We reported that the safe drinking water arsenic standards were recommended to be 2.2 and $1 \mu \mathrm{g} / \mathrm{L}$ for male and 6 and $2.8 \mu \mathrm{g} / \mathrm{L}$ for female in 0-6 and 7-18 years age groups, respectively, based on hyperpigmentation with an excess risk of $10^{-3}$ for a 75 years lifetime exposure. Risk predictions indicate that estimated ORs have 95\% confidence intervals of 1.33-5.12, 1.74-19.15, and 2.81-19.27 based on mean drinking water arsenic contents of 283.19, 282.65, and $468.81 \mu \mathrm{g} / \mathrm{L}$, respectively, in West Bengal, India, Bangladesh, and southwestern Taiwan. Our findings also suggest that increasing urinary monomethylarsonic acid (MMA) levels are associated with an increase in risks of arsenic-induced children skin lesions.
\end{abstract}

C 2007 Elsevier B.V. All rights reserved.

\section{Introduction}

Ingested inorganic arsenic that is known to have adverse health effects are thought to contribute to some complex diseases such as skin lesions, diabetes, cardiovascular disease, and cancers of several organs (lung, bladder, kidney) in arseniasis-endemic area in southwestern and northeastern Taiwan (Chen et al., 2001, 2005; Chiou et al., 2001, 2005; Hsueh et al., 2003; Lamm et al., 2006; Navas-Acien et al., 2005; Smith et al., 2002; Yang et al., 2003a,b, 2005).

Chronic toxicity is observed from exposure to drinking water that contains ppb levels of inorganic arsenic (NRC, 2001a,b). Chronic arsenic exposure and skin lesions (such as keratosis and hyperpigmentation) are inextricably linked (Ahsan et al., 2000; Caldwell et al., 2006; Guha Mazumder et al., 1998; McCarty et al., 2006, 2007; McDonald et al., 2006; Rahman et al., 2006a,b; Yu et al., 2003).

Early effects of exposure to arsenic in drinking water included pigmentation changes and hyperkeratosis (IARC 2004; Smith et al., 2000), which reportedly appeared after 5-10 years of exposure (Guha Mazumder et al., 1998). These skin lesions may develop into more serious and disabling forms, including cancer (Tseng 1977; Guha Mazumder et al., 1998; Tondel et al., 1999; NRC 2001a,b; WHO/IPCS 2001; Haque et al., 2003; IARC 2004).

\footnotetext{
* Corresponding author. Tel.: +886 22363 4512; fax: +886 223626433.

E-mail address: cmliao@ntu.edu.tw (C.-M. Liao).
} 
Some evidence suggests that arsenic-induced skin lesions are early biomarkers of other outcomes such as nonmelanoma skin cancer and cancer of the internal organs (Cuzick et al., 1982, 1984, 1992; Sun et al., 2007; Tseng et al., 1968; Tseng, 1977). There is, however, no effective therapy for skin lesions nowadays (Bhattacharjee, 2007). Recently, health effects for arsenic exposure in young children (0-6 years old) have become a regulatory focus (ATSDR, 2000; USEPA, 2001, 2002). Data to assess direct impacts of arsenic exposure on the children arsenic-induced skin lesions are limited but consistently indicate that they have been posed the potential risks (Rahman et al., 2006a,b; Sun et al., 2007; Tseng et al., 1968). Tseng et al. (1968) and Tseng (1977) reported that the youngest patients with hyperpigmentation were $3-5$, whereas the youngest with keratosis were 4-15 years, implicating that hyperpigmentation could occur in patients who have been exposed for at least 5 years and keratosis for 14 years.

Arsenic methylation of urinary arsenic species is strong associated with skin lesions (Chen et al., 2003a,b; McCarty et al., 2007; Sun et al., 2007; Valenzuela et al., 2005). Chowdhury et al. (2003) indicated that primary methylation ratio $(\mathrm{MMA} /(\mathrm{As}(\mathrm{III})+\mathrm{As}(\mathrm{V})))$ was more active in adults than children, whereas secondary methylation ratio (DMA/MMA) was more active in children than adults. Valenzuela et al. (2005) suggested that MMA(III) levels in urine may serve as an indicator to identify individuals with increased susceptibility to skin lesions of inorganic arsenic exposure. Sun et al. (2007) indicated that children had higher capacity for secondary methylation of arsenic than adults when exposed to the same concentration of inorganic arsenic in drinking water. They concluded that exposure to arsenic may increase the capacity for methylation in children to some extent, implicating that children may benefit from having better secondary methylation than adults. McCarty et al. (2007) suggested that increasing primary methylation ratios were associated with an increase in risk of arsenic-induced skin lesions.

In light of this relationship between arsenic methylation capacity and children skin lesions and its effect on manifestation

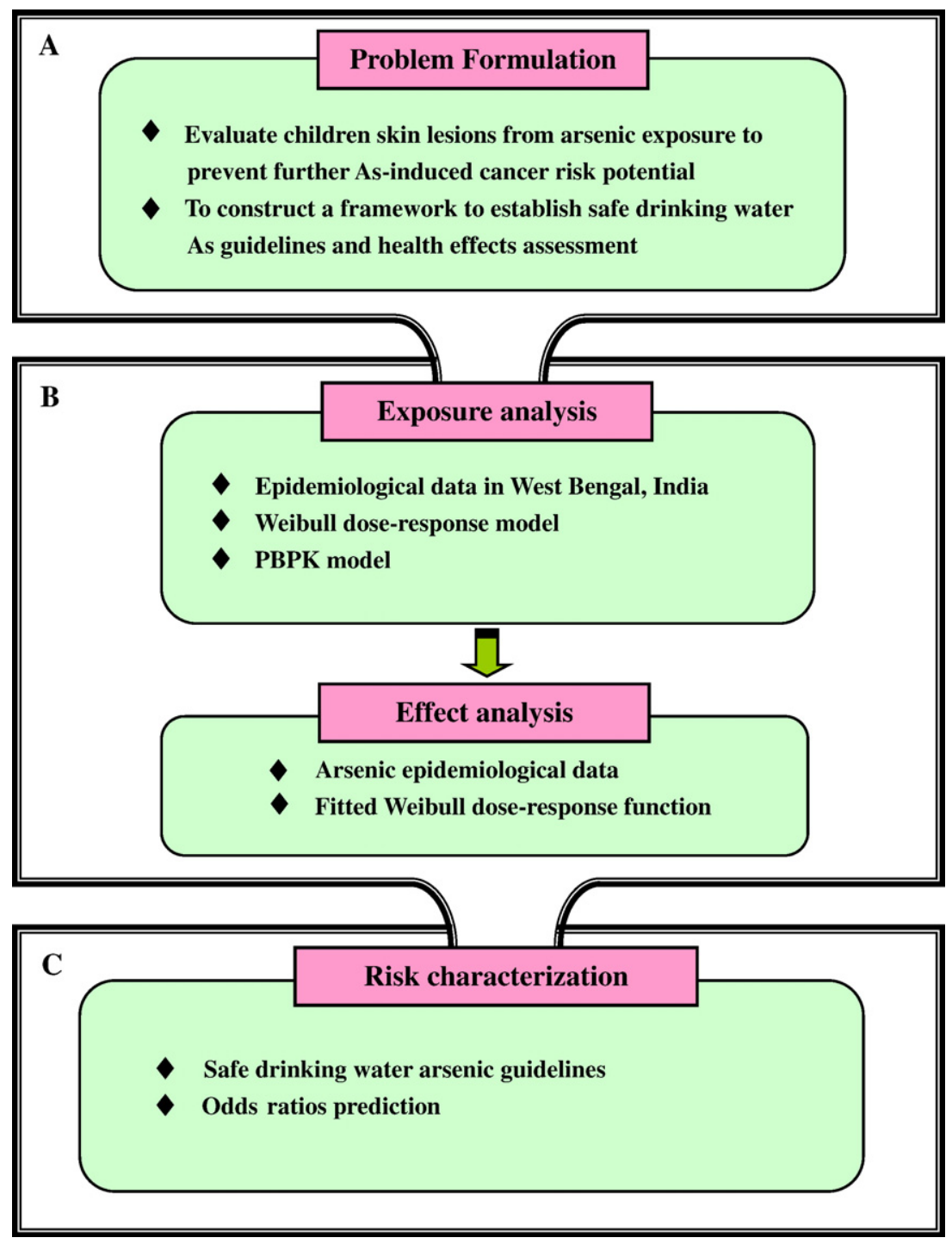

Fig. 1-Schematic showing the proposed risk analysis framework for estimating the safe arsenic water guidelines and odds ratio predictions. The methodology was modified from USEPA (1998). 
of skin cancer, we selected arsenic-induced skin lesions as a model system in which to predict children safe arsenic intake and to assess health effects in arseniasis-endemic areas based on a model-based risk assessment framework. Here we linked a physiologically based pharmacokinetic (PBPK) with a Weibull based dose-response model to formulate the mechanistic model.

The most recent PBPK models for arsenic have a number of similarities (Easterling et al., 2002; Evans and Eklund, 2001; Gentry et al., 2004; Kenyon et al., 2003; Kitchin et al., 1999; Mann et al., 1996a,b; Yu, 1998, 1999a,b). The simplest PBPK model for arsenic came from Yu (1999a). Yu (1998) extended the simplest PBPK model to fit the human child including all arsenic species, As(V), As(III), MMA, and DMA, and considering both reductive metabolism and methylation. Yu (1998) noted that reduction of $\mathrm{As}(\mathrm{V})$ to $\mathrm{As}(\mathrm{III})$ is a second-order process, dependent on the concentration of both $\mathrm{As}(\mathrm{V})$ and glutathione (GSH), suggesting the potential use of a GSH synthesis/depletion submodel linked to the primary kinetic model through the process of arsenic reduction. Yu (1999b) further refined the model to fit the human adult, indicating that the input parameters that most significantly affected the output of the model were the maximum methylation reaction rate, the level of GSH for determination of the reaction rate of $\mathrm{As}(\mathrm{V})$ to $\mathrm{As}(\mathrm{III})$, and the urinary excretion constants.

There are three empirical dose-response models (log-logit, log-probit, and Weibull) that have received some attentions. At high doses, all three models are quite similar. At low doses, however, the log-logit and Weibull models are linear on a loglog scale, whereas the log-probit model has a substantial curvature and gives a much lower risk estimates. Christensen and Nyholm (1984), ten Berge (1999), and Kodell et al. (2006) suggested that the Weibull model was particularly well suited for a long-term low dose exposure purpose on dose-response modeling on lifetime cancer risk estimation.

The main aim of this study is to quantify children skin lesions from arsenic in drinking water and to further estimate the safe drinking water arsenic guidelines based on the proposed PBPK and Weibull model-based epidemiological framework on the basis of gender/age-specific epidemiological data on arsenic exposure, skin lesions prevalence, and atrisk population obtained from studies conducted in arseniasis-endemic areas such as West Bengal, India and Bangladesh and BFD-endemic area in Taiwan.

\section{Materials and methods}

Our risk assessment approach can be divided into four phases (Fig. 1) based on USEPA ecological risk assessment paradigm (USEPA, 1998) to account for the Weibull-PBPK model based framework responds to a spectrum of adverse health effects of arsenic-induced skin lesions that have been identified across a wide range of gender/age-specific scales and is described in subsequent sections.

\subsection{Quantitative arsenic epidemiological data}

A remarkable dataset related to arsenic epidemiology of gander-specific and age-adjusted prevalence of arsenicinduced skin lesions of keratosis and hyperpigmentation in
West Bengal, India (Guha Mazumder et al., 1998) give us the opportunity to test all theoretical considerations of arsenic exposure effects and quantify its strength. We appraise the dataset from the cross-sectional survey conducting between April 1995 and March 1996 to quantitatively reconstruct pooled arsenic epidemiological data of gender- and skin lesionspecific cumulative prevalence ratios (Fig. 2). A total of 7818 individuals participated in the drinking water study. Waterarsenic levels were obtained for 7683 of the participants (4093 females and 3590 males). Guha Mazumder and co-workers (1998) used a standardized questionnaire interview to collect information including sources of drinking water, current diet and water intake, medical symptoms, height and weight and a general medical examination was also given. A detailed description of the recruitment procedure for cross-sectional survey and skin lesions cases ascertainment of keratosis and hyperpigmentation has been reported previously (Guha Mazumder et al., 1998).

Guha Mazumder et al. (1998) indicated that the age-adjusted prevalence of keratosis was strongly related to water arsenic levels, rising from zero in the lowest exposure level $\left(<50 \mu \mathrm{g} \mathrm{L}^{-1}\right)$ to $8.3 \times 10^{-2}$ for female drinking water containing $>800 \mu \mathrm{g} \mathrm{L}^{-1}$, and increasing from $0.2 \times 10^{-2}$ in lowest exposure category to $10.7 \times 10^{-2}$ for male in the highest exposure level $\left(>800 \mu \mathrm{g} \mathrm{L}^{-1}\right)$. On the other hand, findings were similar for hyperpigmentation with strong dose-response relationships. The larger number of study participants, 1-year follow-up with more skin lesions cases, and wider range of arsenic exposure levels $\left(<50->800 \mu \mathrm{g} \mathrm{L}^{-1}\right)$ and gender specific age groups (<9-> 60 years) leads us with a unique opportunity to further investigate the dose-response relationship between ingested arsenic exposure and skin lesions risks.

\subsection{Weibull dose-response model}

Here we use the Weibull probability density function to account for the age-specific prevalence ratio for human longterm exposure to low doses of arsenic,

$g(t, \varepsilon(C))=\varepsilon(C) k_{2} t^{k_{2}-1} \exp \left(-\varepsilon(C) t^{k_{2}}\right)$

with

$\varepsilon(C)=k_{0} C^{k_{1}}+k_{3}$,

where $g(t, \varepsilon(C))$ represents the skin lesion-specific prevalence ratio for human exposed to arsenic concentration $C\left(\mu \mathrm{g} \mathrm{L}^{-1}\right)$ at age $t$ (year), $\varepsilon(C)$ is the $C$-dependent shape parameter, and $k_{0}$, $k_{1}, k_{2}$, and $k_{3}$ are the skin lesion-specific best-fitted parameters. The cumulative prevalence ratio for human exposed to arsenic concentration $C$ at age $t$ can then be obtained by integral of Eq. (1) as,

$$
\begin{aligned}
P(t, C) & =\int_{0}^{t} g(t, \varepsilon(C)) d t=1-\exp \left(-\varepsilon(C) t^{k_{2}}\right) \\
& =1-\exp \left(-\left(k_{0} C^{k_{1}}+k_{3}\right) t^{k_{2}}\right)
\end{aligned}
$$

We employed TableCurve 3D (Version 4, AISN Software Inc., Mapleton, OR, USA) to perform model fitting to pooled published arsenic epidemiological data to reflect the reasonable trend of dose-response relationships (Fig. 2). 

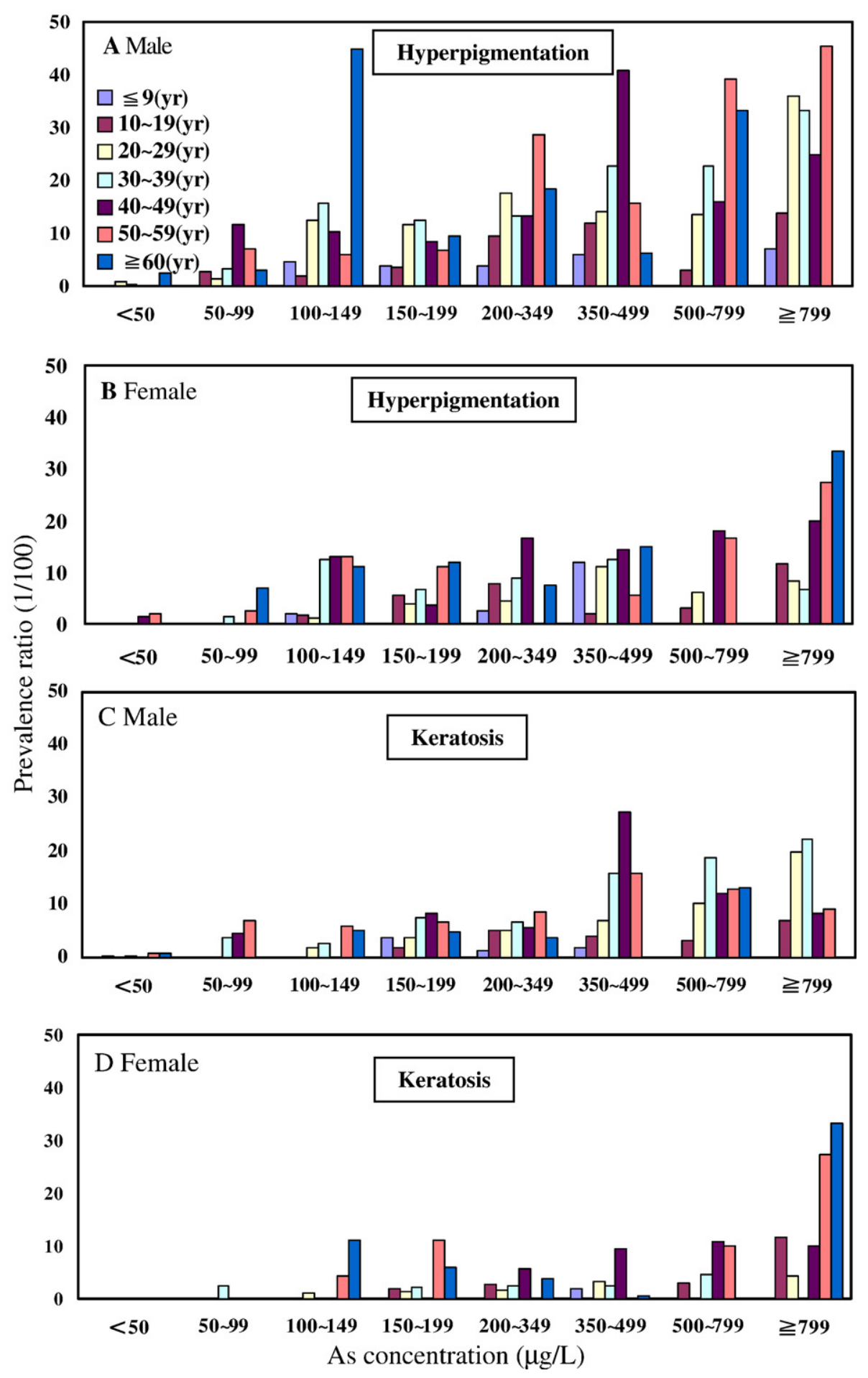

Fig. 2-Reanalyzed published arsenic epidemiological data of gender- and skin lesion-specific prevalence ratios in West Bengal, India, showing the male/female hyperpigmentation (A, B), and keratosis (C, D).

\subsection{PBPK model}

We appropriately refine the basic compartmental structure that has been previously employed in many PBPK models for arsenic exposure in humans (Mann et al., 1996a,b; Yu, 1998, 1999b) to describe the pharmacokinetics and metabolism of arsenic in target organs. The tissue compartments included in the model were (Fig. 3A): Lung, liver, kidney, GI tract, skin, muscle, fat tissues in that each tissue compartment is interconnected by blood flow. The biotransformation of arsenic in the body consists of an oxidation/ reduction and two methylation reactions (Fig. 3B). The oxidation/reduction of inorganic arsenic takes place in the plasma and in the kidney and liver, whereas the methylation 


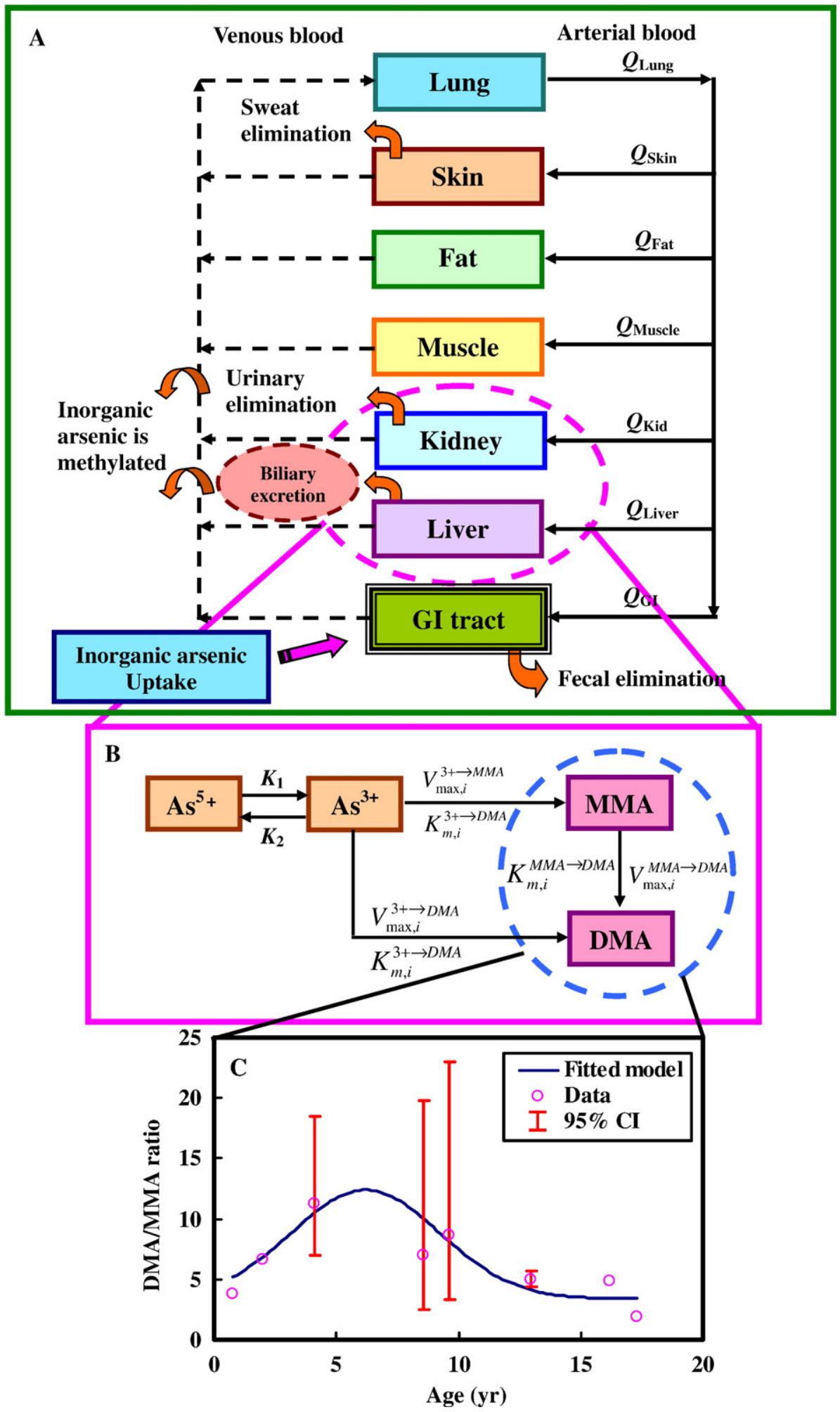

Fig. 3-Schematic of the proposed PBPK-metabolism model showing (A) target tissue compartments of lung, skin, fat, muscle, kidney, liver and GI tract interconnected by blood flow, (B) biotransformation of arsenic showing oxidation/reduction of inorganic arsenic and methylation of As(III) in kidney and liver, and (C) the age-specific secondary methylation ratio (DMA/ MMA) distributions adopted from Chowdhury et al. (2003).

of As(III) takes place mainly in the liver and kidney according to Michaelis-Menten kinetics (Yu, 1998, 1999b). Mann et al. (1996a,b) suggested that the reduction of As(V) to As(III) can be modeled as a first-order oxidation/reduction reaction. Here we assume kidney and urine having the same levels of arsenic species. 
Table 1 - Weibull model fitting parameters (mean with $95 \% \mathrm{CI}$ ) for male and female of hyperpigmentation and keratosis

\begin{tabular}{|c|c|c|c|c|}
\hline & \multicolumn{2}{|c|}{ Hyperpigmentation } & \multicolumn{2}{|c|}{ Keratosis } \\
\hline & Male & Female & Male & Female \\
\hline$k_{0}$ & $\begin{array}{l}5.41 \times 10^{-4} \\
\left(0-1.3 \times 10^{-3}\right)\end{array}$ & $\begin{array}{l}2.95 \times 10^{-4} \\
\left(0-8.15 \times 10^{-4}\right)\end{array}$ & $\begin{array}{l}1.44 \times 10^{-4} \\
\left(0-3.02 \times 10^{-4}\right)\end{array}$ & $\begin{array}{l}8.79 \times 10^{-5} \\
\left(0-2.55 \times 10^{-4}\right)\end{array}$ \\
\hline$k_{1}$ & $0.62(0.43-0.82)$ & $0.61(0.37-0.85)$ & $0.70(0.55-0.85)$ & $0.65(0.39-0.91)$ \\
\hline$k_{2}$ & $0.18(0.12-0.24)$ & $0.17(0.10-0.24)$ & $0.18(0.13-0.23)$ & $0.12(0.047-0.19)$ \\
\hline$k_{3}$ & $\begin{array}{l}1.00 \times 10^{-4} \\
\left(0-4.98 \times 10^{-3}\right)\end{array}$ & $\begin{array}{l}1.00 \times 10^{-4} \\
\left(0-3.21 \times 10^{-3}\right)\end{array}$ & $\begin{array}{l}1.00 \times 10^{-4} \\
\left(0-1.51 \times 10^{-3}\right)\end{array}$ & $\begin{array}{l}1.00 \times 10^{-4} \\
\left(0-1.30 \times 10^{-3}\right)\end{array}$ \\
\hline$r^{2}$ & 0.94 & 0.91 & 0.96 & 0.91 \\
\hline
\end{tabular}

We employed age-specific secondary methylation ratio (DMA/MMA) distributions to adjust the age-dependent arsenic methylation rate constants based on a study focused on the excretion of arsenic species in urine of children compared to adults from an arsenic exposed area in Bangladesh (Chowdhury et al., 2003), resulting in a fitted normal distribution of $y=1.32+2.56 \exp \left(-0.5((x-0.54) / 1.0)^{2}\right)\left(r^{2}=0.80, p<0.05\right)$ (Fig. 3C). The dynamic behavior of PBPK and metabolic processes in the PBPK model can be described by a set of firstorder differential equations (see Appendix A for detail). The physiological parameters, age-adjusted metabolic constants, tissue/blood partition coefficients, and biochemical parameters are listed in Tables B1, B2, and B3 (Appendix B). We employed the MATLAB ${ }^{\circ}$ software (The Mathworks Inc., MA, USA) to perform the PBPK simulations.

\subsection{Quantitative safe arsenic intake and risk estimates}

We assume daily water uptake rate undergoes a variability analysis. We transform arsenic exposure-response relationship into internal dose-based response function by incorporating PBPK

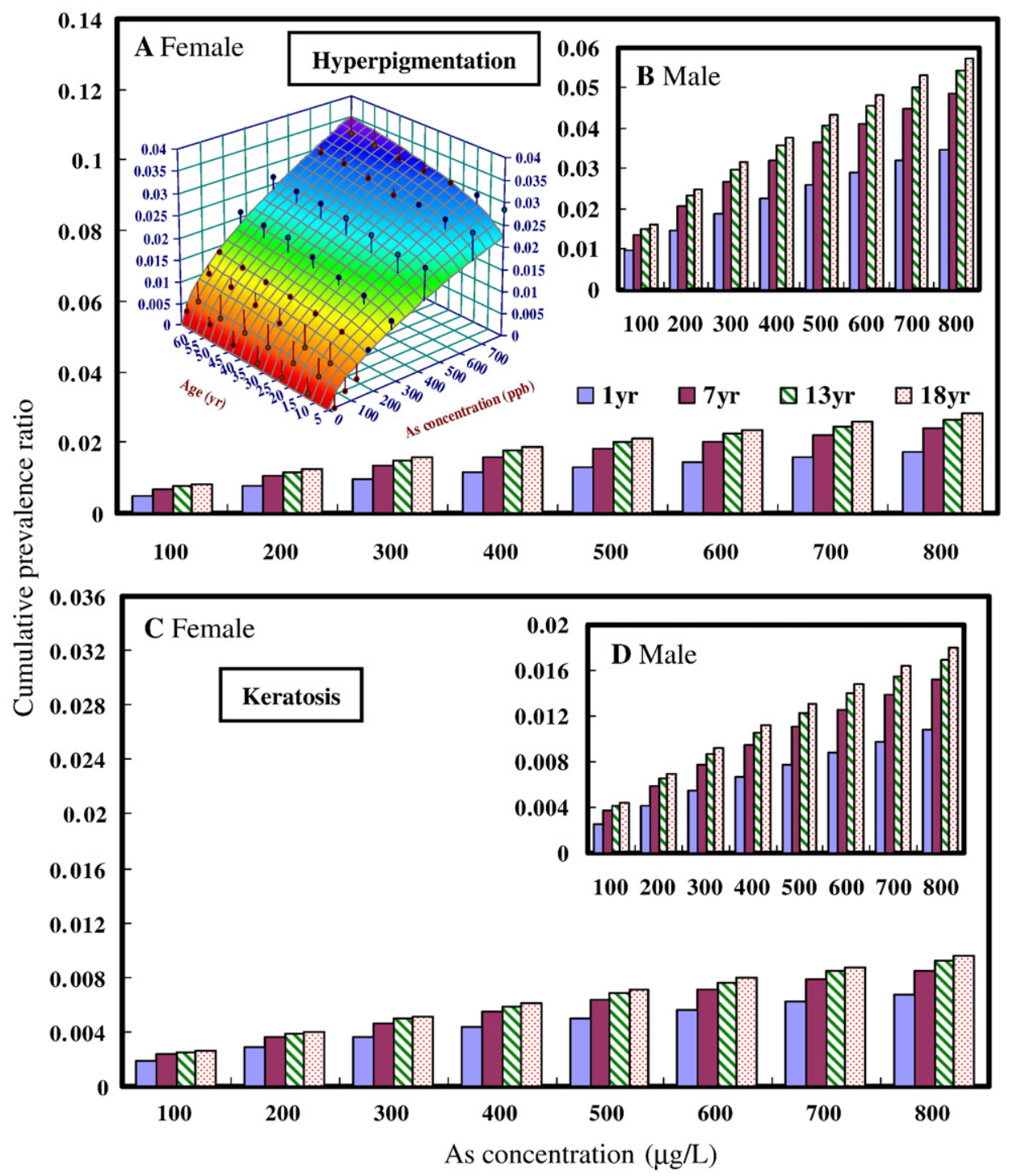

Fig. 4-Weibull model predicted age-specific skin lesions cumulative prevalence ratios varied with arsenic exposure for female/ male hyperpigmentation (A, B), and keratosis (C, D). Inset illustrates the best fitted Weibull model-based dose-response surface for female hypermentation. 

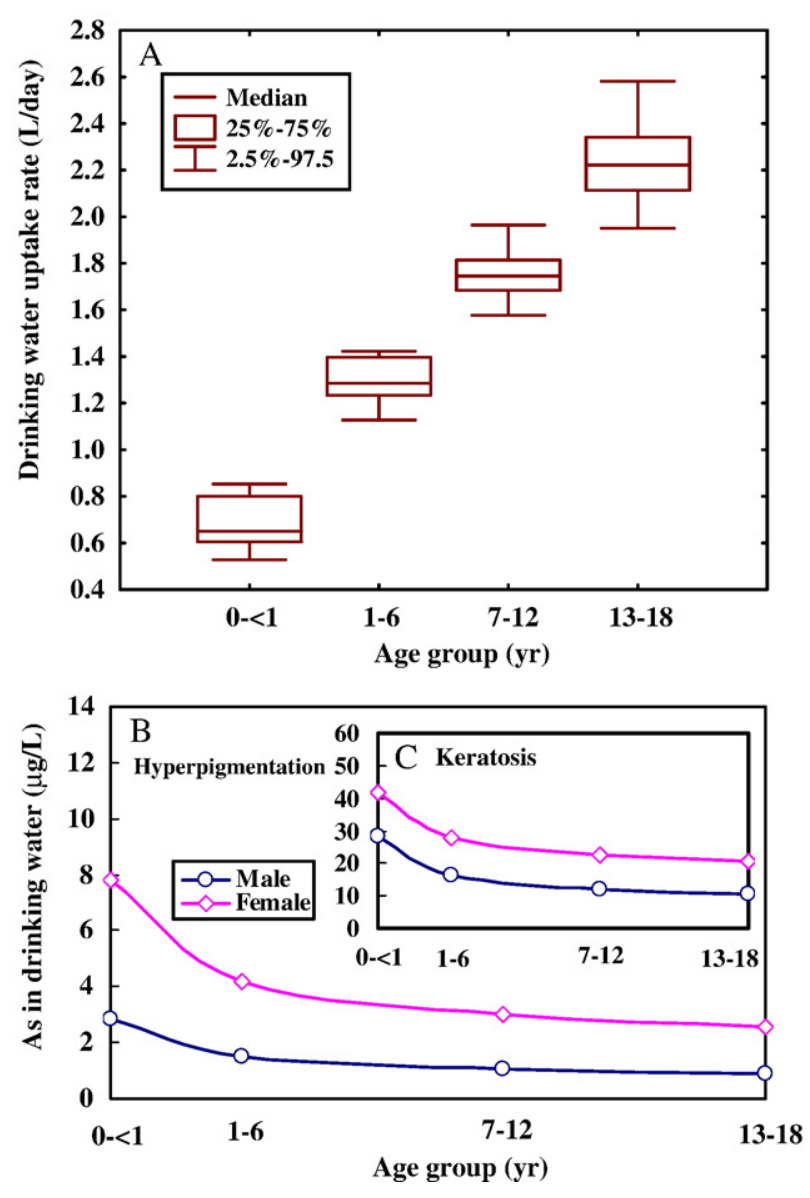

Fig. 5-(A) Box and whisker plot showing the daily drinking water uptake rate distribution for four age groups of $0-<1$, 1-6, 7-12, and 13-18 year, respectively, and the gender-specific safe drinking water arsenic concentration estimates for (B) hyperpigmentation and (C) keratosis, respectively, varied with different children age groups.

model into Weibull model to account for the variability of risk estimates and safe drinking water arsenic concentration based on drinking water uptake rate distribution. Morales et al. (2000) suggested that the use of $1 \%$ and $5 \%$ excess risks $\left(\triangle E D_{01}\right.$ and $\triangle E D_{05}$, respectively) for the point-of-departure analysis for cancer risk assessment suggested by USEPA (1996) are better than that of $10 \%$ excess risk $\left(\triangle E D_{10}\right)$ because an excess risk of $10 \%$ is relatively large and happens only at relative high doses in epidemiological studies.

The USEPA suggested point-of-departure analysis for cancer risk assessment is to estimate a point on the exposure response curve within the observed range of the data and then extrapolate linearly to lower dose (Morales et al., 2000). Morales et al. (2000) also pointed out that traditionally employed unit excess lifetime risk of $10^{-6}$ is probably unreliable for epidemiological data where exposure is not typically measured accurately enough to extrapolate to such low risk levels. In the present study, we use $0.1 \%$ excess risk $\left(\Delta E D_{0.1}\right)$ point-ofdeparture to predict the safe drinking water arsenic intake guideline based on the published reports of prevalence ratios on health effects in Bangladesh (hyperpigmenation, male: 1.35\%, female: $0.63 \%$; keratosis, male: $0.63 \%$, female: $0.34 \%$ ) (Yu et al.,

Table 2 - Recommended safe arsenic concentration ( $\mu \mathrm{g} / \mathrm{L}$ ) in drinking water with hyperpigmentation and keratosis of males based on $\mathrm{ED}_{0.1}$

\begin{tabular}{lcccc} 
Gender & \multicolumn{4}{c}{ Age group (year) } \\
\cline { 2 - 5 } & $0-<1$ & $1-6$ & $7-12$ & $13-18$ \\
\hline Hyperpigmentation & & & & \\
Male & 2.82 & 1.51 & 1.08 & 0.91 \\
Female & 7.83 & 4.20 & 3.02 & 2.56 \\
Keratosis & & & & \\
Male & 28.22 & 16.13 & 11.98 & 10.32 \\
Female & 41.77 & 28.00 & 22.7 & 20.45 \\
\hline
\end{tabular}

2003), in West Bengal, India (hyperpigmentation, male: $6.4 \%$, female: $3.1 \%$; keratosis, male: $3.0 \%$, female: $1.2 \%$ ) (Guha Mazumder et al., 1998), and in southwestern Taiwan (hyperpigmentation: 18.3\%; keratosis: 7.1\%) (Tseng et al., 1968).

We calculate odds ratios (ORs) to assess the relative magnitude of the effect of the arsenic exposure on the likelihood of the prevalence of children skin lesions at a particular setting by calculating proposed Weibull-based prevalence ratios of exposed to control groups associated with the age group-specific PBPK model predicted MMA(III) levels in urine. The MMA(III) level in urine is calculated based on the proportions of $7.4 \%$ of MMA(III) and $2.8 \%$ of MMA(V) in total urinary MMA (Valenzuela et al., 2005). Odds are the probability of an event occurring divided by the probability of it not occurring. Thus, the OR can be defined in terms of

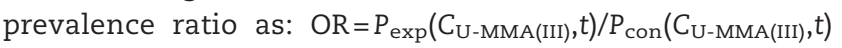
where subscripts exp, con, and U-MMA(III) represent exposed, control, and urinary MMA(III) level, respectively.

To explicitly quantify the uncertainty/variability of data, a Monte Carlo simulation is performed with 10,000 iterations (stability condition) to obtain the $95 \%$ confidence interval (CI). The Monte Carlo simulation is implemented by using the Crystal Ball software (Version 2000.2, Decisioneering Inc., Denver, CO, USA). The $\chi^{2}$ and Kolmogorov-Smirnov (K-S) statistics were used to optimize the goodness-of-fit of the distribution.

\section{Results}

\subsection{Fitting Weibull model to arsenic epidemiological data}

Table 1 shows the best-fitted parameters $k_{0}, k_{1}, k_{2}$, and $k_{3}$ in Eq. (3) for hyperpigmentation and keratosis for each gender by fitting Weibull dose-response function (Eq. (3)) to gender- and skin lesion-specific cumulative prevalence ratios (Fig. 2). Here we estimate Weibull dose-response function for the background prevalence of skin lesions and for the total incidence at a given arsenic concentration. We obtain Eq. (3) by incorporating a background dose response function into the original dose-response function.

Our results indicate that male skin lesions have the highest $r^{2}$ values $(0.94-0.96)$ than those of female skin lesions $\left(r^{2}=0.91\right)$ (Table 1). Specifically, arsenic exposure has notably influence than that of age $\left(k_{1}=0.61-0.70, k_{2}=0.12-0.18\right)$ for all gender skin 

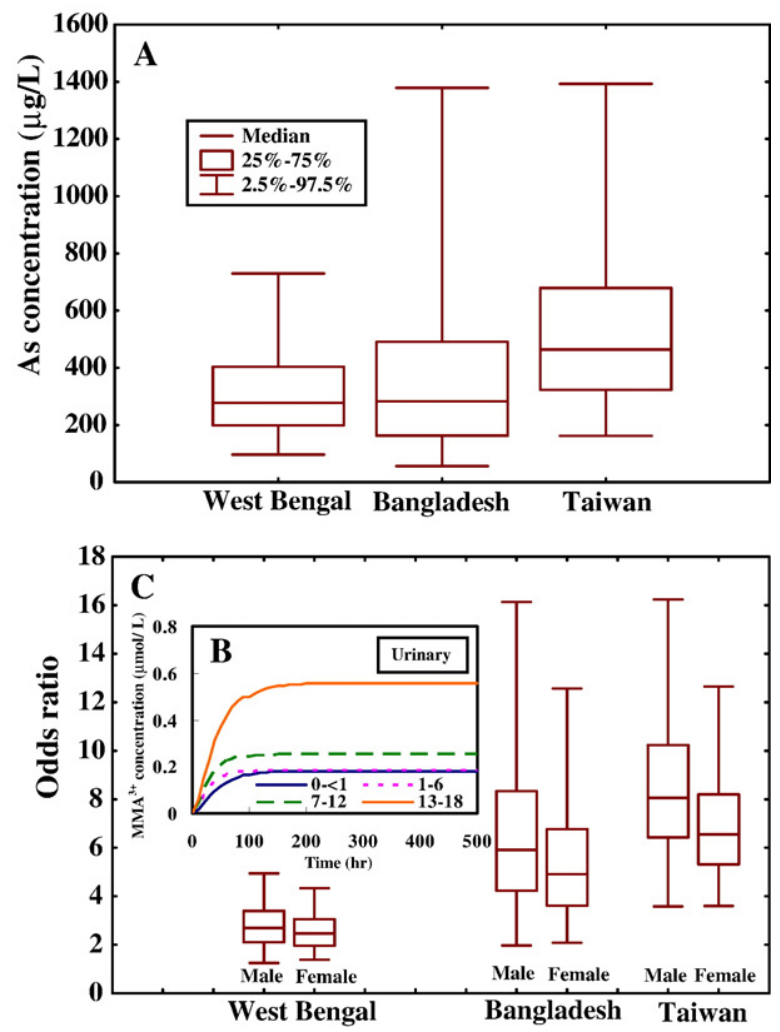

Fig. 6-(A) Box and whisker plots showing the best fitted lognormal distribution of arsenic concentration in well water, respectively, in West Bengal, India, Bangladesh, and southwestern Taiwan, (B) age group-specific urinary MMA (III) levels calculated from PBPK model for four age groups in children, and (C) box and whisker plots showing the predicted odds ratio distributions in West Bengal, India, Bangladesh, and southwestern Taiwan in that the symbols indicate the published data.

lesions, implicating that arsenic exposure is the major attribute to skin lesion prevalence ratio for the study participants of residents in West Bengal, India (Table 1). The response surfaces of doseresponse function associated with an age-specific relationship between cumulative prevalence ratio and arsenic exposure can be fit reasonably well by Weibull model (Fig. 4A). A similar trend of arsenic exposure specific cumulative prevalence ratio for gender/ age specific skin lesions is predicted for ages of the 1st, 7th, 13th, and 18th year, indicating that cumulative prevalence ratios of skin lesions increase with increasing arsenic exposure and age (Fig. 4).

\subsection{Safe drinking water arsenic estimates}

We use fitted Weibull model to further estimate the age-specific safe drinking water arsenic concentrations based on Fig. 4 with excess risk of $10^{-3}$ and age-specific median daily drinking water uptake rates of $0.65,1.29,1.75$, and $2.22 \mathrm{~L} \mathrm{~d}^{-1}$, respectively for four age groups (Fig. 5, Table 2). Table 2 shows that the safe water inorganic arsenic concentrations are estimated to be 2.82, 1.51, 1.08 , and $0.91 \mu \mathrm{g} \mathrm{L}^{-1}$ for male hyperpigmentation, whereas the safe arsenic estimates for male keratosis are 28.21, 16.13, 11.98, and $10.32 \mu \mathrm{g} \mathrm{L}^{-1}$, in age groups of $0-<1,1-6,7-12$, and 13-18 years, respectively, based on a $0.1 \%$ excess risk $\left(\Delta \mathrm{ED}_{0.1}\right)$.

\subsection{Risk prediction of children skin lesions}

We applied the proposed Weibull-PBPK model to predict and evaluate children skin lesions health effects in West Bengal, India, Bangladesh, and southwestern Taiwan where comprehensive studies of arsenic-induced skin lesions have not been fully conducted to date. The best fitted lognormal distributions (LN(geometric mean, geometric standard derivation) of arsenic concentrations in well water of surveyed villages in West Bengal, India (LN(283.19 $\left.\mu \mathrm{g} \mathrm{L}^{-1}, 1.69\right)$, Bangladesh (LN (282.65 $\left.\left.\mu \mathrm{g} \mathrm{L} \mathrm{L}^{-1}, 2.27\right)\right)$, and southwestern Taiwan (468.81 $\mu \mathrm{g} \mathrm{L}^{-1}$, 1.73)) (Fig. 6A) were calculated based on the published data, respectively, from Haque et al. (2003), Chowdhury et al. (2000), and Tseng et al. (1968) in that the control arsenic exposure levels were 50,10, and $10 \mu \mathrm{g} \mathrm{L}^{-1}$, respectively, in West Bengal, India, Bangladesh, and southwestern Taiwan.

We predict OR by incorporating age group-specific urinary MMA(III) levels calculated from PBPK model (Fig. 6B) into Weibull dose-response model. The results demonstrate that male ORs are greater than that of female among the four children age groups, whereas the ORs of hyperpigmentation are greater than that of keratosis increasing with increased ages in West Bengal, India, Bangladesh, and southwestern Taiwan (Table 3, Fig. 6C). The findings depicted in Table 3

Table 3-Odds ratio estimates for gender-specific hyperpigmentation and keratosis in West Bengal, India, Bangladesh, and southwestern Taiwan

\begin{tabular}{|c|c|c|c|c|}
\hline \multirow{3}{*}{$\begin{array}{l}\text { Age group } \\
\text { (year) }\end{array}$} & \multicolumn{4}{|c|}{ Odds ratio } \\
\hline & \multicolumn{2}{|c|}{ Hyperpigmentation } & \multicolumn{2}{|c|}{ Keratosis } \\
\hline & Male & Female & Male & Female \\
\hline \multicolumn{5}{|l|}{ West Bengal } \\
\hline $0-<1$ & $\begin{array}{l}2.73 \\
(1.46-4.93)\end{array}$ & $\begin{array}{l}2.53 \\
(1.41-4.44)\end{array}$ & $\begin{array}{l}2.51 \\
(1.38-4.61)\end{array}$ & $\begin{array}{l}2.25 \\
(1.33-3.88)\end{array}$ \\
\hline $1-6$ & $\begin{array}{l}2.73 \\
(1.46-4.93)\end{array}$ & $\begin{array}{l}2.54 \\
(1.71-4.44)\end{array}$ & $\begin{array}{l}2.52 \\
(1.38-4.62)\end{array}$ & $\begin{array}{l}2.25 \\
(1.33-3.88)\end{array}$ \\
\hline $7-12$ & $\begin{array}{l}2.76 \\
(1.47-4.99)\end{array}$ & $\begin{array}{l}2.58 \\
(1.42-4.54)\end{array}$ & $\begin{array}{l}2.63 \\
(1.41-4.89)\end{array}$ & $\begin{array}{l}2.35 \\
(1.35-4.11)\end{array}$ \\
\hline $13-18$ & $\begin{array}{l}2.82 \\
(1.48-5.12)\end{array}$ & $\begin{array}{l}2.67 \\
(1.45-4.75)\end{array}$ & $\begin{array}{l}2.86 \\
(1.47-5.47)\end{array}$ & $\begin{array}{l}2.56 \\
(1.41-4.61)\end{array}$ \\
\hline \multicolumn{5}{|l|}{ Bangladesh } \\
\hline $0-<1$ & $\begin{array}{l}6.48 \\
(2.52-17.12)\end{array}$ & $\begin{array}{l}5.35 \\
(2.23-5.35)\end{array}$ & $\begin{array}{l}4.54 \\
(1.89-12.56)\end{array}$ & $\begin{array}{l}3.76 \\
(1.74-9.40)\end{array}$ \\
\hline $1-6$ & $\begin{array}{l}6.48 \\
(2.52-17.12)\end{array}$ & $\begin{array}{l}5.36 \\
(2.23-13.55)\end{array}$ & $\begin{array}{l}4.55 \\
(1.90-12.61)\end{array}$ & $\begin{array}{l}3.77 \\
(1.74-9.43)\end{array}$ \\
\hline $7-12$ & $\begin{array}{l}6.70 \\
(2.58-17.78)\end{array}$ & $\begin{array}{l}5.63 \\
(2.31-14.34)\end{array}$ & $\begin{array}{l}5.04 \\
(2.02-14.23)\end{array}$ & $\begin{array}{l}4.14 \\
(1.84-10.56)\end{array}$ \\
\hline $13-18$ & $\begin{array}{l}7.16 \\
(2.71-19.15)\end{array}$ & $\begin{array}{l}6.23 \\
(2.48-16.14)\end{array}$ & $\begin{array}{l}6.33 \\
(2.35-18.53)\end{array}$ & $\begin{array}{l}5.12 \\
(2.11-13.63)\end{array}$ \\
\hline \multicolumn{5}{|l|}{ Taiwan } \\
\hline $0-<1$ & $\begin{array}{l}8.76 \\
(4.64-17.23)\end{array}$ & $\begin{array}{l}7.12 \\
(3.91-13.61)\end{array}$ & $\begin{array}{l}6.17 \\
(3.28-12.65)\end{array}$ & $\begin{array}{l}4.95 \\
(2.81-9.46)\end{array}$ \\
\hline $1-6$ & $\begin{array}{l}8.77 \\
(4.65-17.23)\end{array}$ & $\begin{array}{l}7.13 \\
(3.92-13.63)\end{array}$ & $\begin{array}{l}6.20 \\
(3.29-12.69)\end{array}$ & $\begin{array}{l}4.96 \\
(2.82-9.49)\end{array}$ \\
\hline $7-12$ & $\begin{array}{l}9.08 \\
(4.79-17.89)\end{array}$ & $\begin{array}{l}7.52 \\
(4.10-14.43)\end{array}$ & $\begin{array}{l}6.91 \\
(3.60-14.33)\end{array}$ & $\begin{array}{l}5.49 \\
(3.06-10.63)\end{array}$ \\
\hline $13-18$ & $\begin{array}{l}9.73 \\
(5.10-19.27)\end{array}$ & $\begin{array}{l}8.37 \\
(4.50-16.24)\end{array}$ & $\begin{array}{l}8.81 \\
(4.43-18.66)\end{array}$ & $\begin{array}{l}6.91 \\
(3.71-13.72)\end{array}$ \\
\hline
\end{tabular}


indicate that children ages between 7-18 years are at a higher risk of skin lesions to chronic arsenic exposure. The overall predicted OR distributions of children skin lesions (Fig. 6C) gave the mean estimates with $95 \%$ CI of 2.70 (1.26-4.95), 2.47 (1.29-4.33) and 5.92 (1.97-16.13), 4.92 (2.08-12.57) for male and female, respectively, in West Bengal, India and Bangladesh; whereas the risk in southwestern Taiwan was somewhat more greater and had wider ranges of $95 \%$ CI for both male (8.05 (3.58-16.24)) and for female (6.56 (3.61-12.65)).

\section{Discussion}

\subsection{Skin lesions Weibull-PBPK model}

We use Weibull model to estimate dose response function based on the published epidemiological data in West Bengal, India to derive the safe drinking water arsenic guidelines for children skin lesions. We use urinary arsenic species predicted from PBPK model as a biomarker of exposure to relate the exposure characterized by arsenic methylation capacity of urinary arsenic to exposures that may occurred chronically. It is extremely difficult to use the data to extrapolate dose response functions to low arsenic concentrations. The Weibull dose-response function based on our present arsenic epidemiological data should provide better estimates of skin lesions prevalence for areas where arsenic concentrations are high (e.g., Bangladesh and Taiwan) and for areas where incidence/prevalence rates must be extrapolates to low arsenic concentrations (e.g., USA).

Morales et al. (2000) and Yu et al. (2003) indicated that dose response functions of different parametric forms can lead to quite different estimates of incidence rate and prevalence ratio. NRC $(2001 a, b)$ also shows that risk estimates are sensitive to how the data is grouped and to which arsenic concentrations are included in the data. An analysis of the implications of arsenic-induced children skin lesions risks in arseniasis-endemic areas would be more complex and would include consideration of impacts on regionally specific information on social, demographic, and economic trends. Moreover, the arsenic-induced skin lesions risks may occur concurrent with human-induced changes. These humandriven transitions in arseniasis-endemic areas are likely to have a larger impact on risk profiling than arsenic-onlyinduced transitions. Although our information may not be able to provide an unambiguous definition of safe drinking water arsenic and risk estimates, it may help to inform public and regulatory authorities on discussions of risk management and communication by drawing attention to the worldwide arsenic issues.

In view of the higher odds ratio in 13-18 age groups, which may be attributable to the higher drinking water uptake rate (Fig. 5A) and the accumulation of exposure. Tseng et al. (1968) were also pointed out that the prevalence rates of hyperpigmentation and keratosis increased steadily with age for males and females. These lagged effects on chronic arsenic exposure may explain why younger children have lower ORs. Tseng et al. (1968) further indicated that hyperpigmrntation can occur in patients who have been exposed for at least 3 years, keratosis for 4 years, and skin cancer for 24 years.

\subsection{Safe arsenic guideline for children skin lesions}

We recognize limitations in each of our data sources, particularly the inherent problem of uncertainty and variability of the data. The strength of these results rests on the robustness of the Weibull-PBPK model and the public and regulatory authorities' guideline values. Our analysis may provide a wider context for the interpretation of regional arsenic-induced children skin lesions risk profiling that produced diverging and controversial outcomes, which has economic and policy implications. Although more complex models may be necessary to answer specific questions regarding risk or particular management strategies, our simple model captures the essential risk analysis methodology and it's flexible enough to integrate effects occurring at varying subpopulation scales.

We argue that the present safe water arsenic guideline values for children skin lesions are estimated based on arsenic epidemiology data from long-term arsenic exposures and not based on animal models considering uncertainty factors used to account for potential interspecies variation in response sensitivity and potential intraspecies variation in human sensitivity. Yet if we employ $10^{-6}-10^{-4}$ as our unit excess lifetime cancer risk to estimate the safe water arsenic guideline, the guideline value will come out to be nearly $0 \mu \mathrm{g} \mathrm{L}^{-1}$. Consequently, the estimated excess lifetime skin lesions risks from drinking water exceed the range of $10^{-6}-10^{-4}$ and that should be interpreted cautiously to avoid misleading (Brown, 1998; Smith and Sharp, 1985). We suggest that a precautionary approach toward risk management and communication should be given a high priority for reducing children skin lesions risks.

There are a number of areas in which further research may aid in decreasing the uncertainties in model development. First, there is a need to conduct a more extensive characterization of the distribution of exposures within given populations. This would require the collection of more detailed information on arsenic exposure data, arsenic levels in target organs, and site- and species-specific arsenic epidemiological data. It would be useful to characterize better the distribution of siteand gender/age-specific exposures. Second, there is a need for sensitivity analysis using the Monte Carlo simulation model with the more detailed data sets as inputs. The uncertainties may attributable to concentrations of arsenic in well water, numbers of people who are expected to various arsenic concentrations, and dose response function for health effects.

The ranges and distributions of parameters can then be combined by use of the Monte Carlo simulation model to produce a response surface. Relationships between the input ranges and model output should then be assessed with stepwise regression in order to identify the relationship between output variability and input uncertainties and variabilities. Finally, on the basis of the results of the sensitivity analysis, research should be directed to those parameters that, if better characterized, could most effectively reduce variability in the results.

\subsection{Implications}

We propose that this Weibull model-based arsenic epidemiology and PBPK approach, which amounts to arsenic-induced 
children skin lesions risk profiling associated with a proposed safe drinking water arsenic standard, might provide the basis of a future population-based risk management strategy. Furthermore, this approach should have certain advantages over methods for dose response profile selection that are dependent on the use of arsenic epidemiological data to characterize particular aspects of risk analysis. A further inherent benefit of the Weibull-PBPK approach is to provide interplay among system approach, regulatory processes, and risk management.

The main potential application we envisage for WeibullPBPK approach is with respect to human health, and there is clearly a need for further development and to investigate how well the approach can be transferred from West Bengal to Bangladesh or Taiwan populations, for whom much greater chronic arsenic exposure and environmental variation would be expected. Recent developments in data analysis should assist safe drinking water arsenic standard establishment and biomarkers identification of arsenic-induced health hazards (Chen et al., 2005). Metabolite profiling of fluids in PBPK model other than urine and bile, such as blood, hair and nails and fecal excretion, should provide additional information (Brown, 1998).

In closing, we envisage that optimal quantification of skin lesions risks from chronic arsenic exposure in drinking water may eventually involve a variety of dose response-prediction approaches. However, by linking Weibull model-based arsenic epidemiology and PBPK model has an important theoretical advantage over traditional models in that it can potentially take account of both physiological and environmental factors affecting arsenic-induced adverse health responses. Furthermore, although our proposed framework would normally relate to predicting safe drinking water arsenic concentration and the likelihood of risk estimates, we envisage that similar methodology could be applied to predicting potential population-level long-term low dose pre-cancerous and cancer risk responses to broader medical, dietary, microbiological or physiological challenges.

\section{Appendix A. Equations used in the proposed PBPK model}

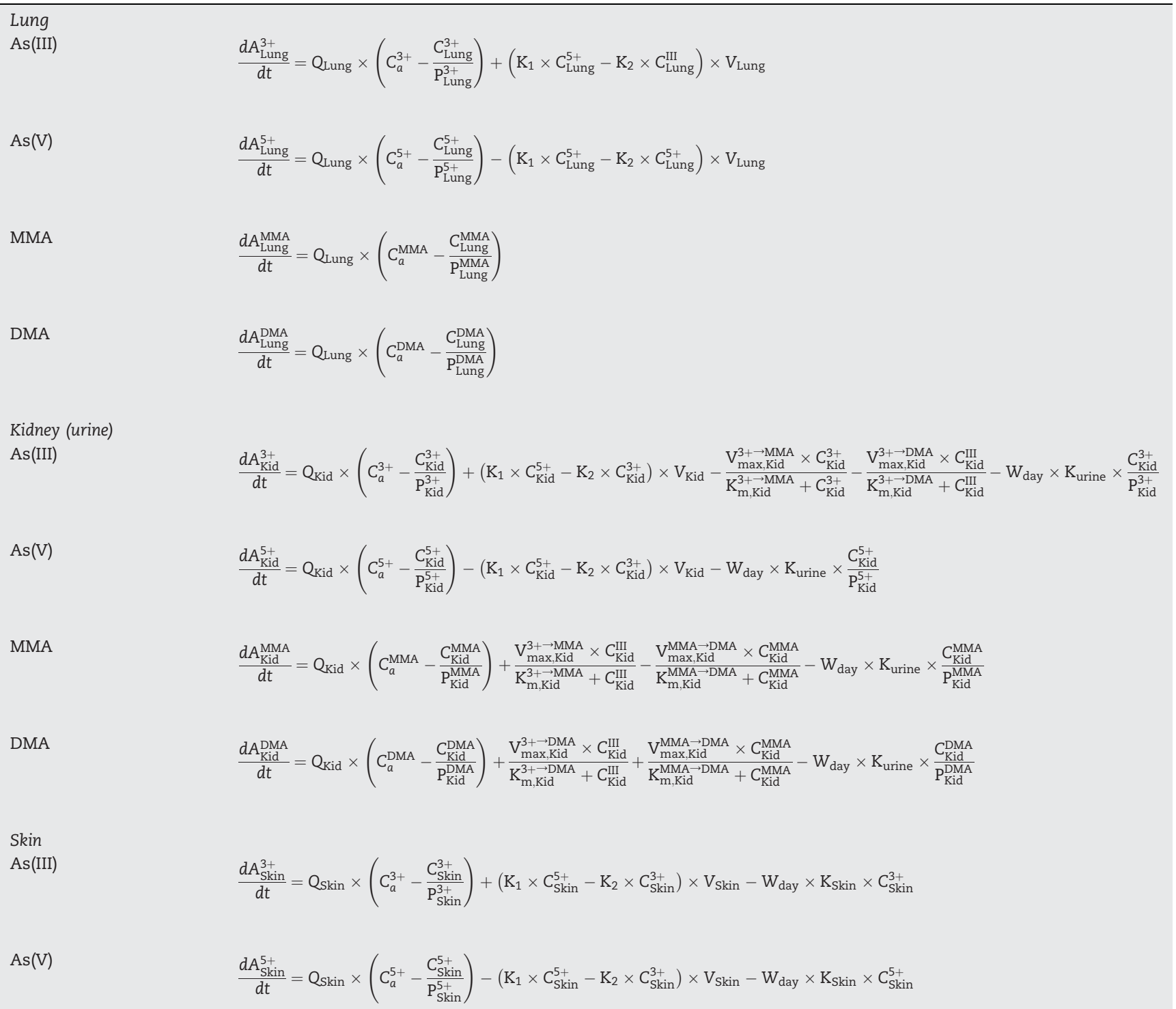


SCIENCE OF THE TOTAL ENVIRONMENT $392(2008) 203-217$

213

Appendix A (continued)

Skin

MA

DNA

G.I. tract

As(III)

$\operatorname{As}(\mathrm{V})$

AMA

DNA

Liver

As(III)

$\operatorname{As}(\mathrm{V})$

MA

DNA

Muscle

As(III)

$\operatorname{As}(\mathrm{V})$

AMA

DNA

Fat

As(III)

$$
\frac{d A_{\text {Skin }}^{\text {MIA }}}{d t}=Q_{\text {Skin }} \times\left(C_{a}^{\text {MIA }}-\frac{C_{\text {Skin }}^{\text {MIA }}}{P_{\text {Skin }}^{M M A}}\right)-W_{\text {day }} \times K_{\text {Skin }} \times C_{\text {Skin }}^{\text {MIA }}
$$$$
\frac{d A_{\text {Skin }}^{\text {DNA }}}{d t}=Q_{S k i n} \times\left(C_{a}^{\text {DNA }}-\frac{C_{\text {Skin }}^{\text {DNA }}}{P_{\text {Skin }}^{\text {DNA }}}\right)-W_{\text {day }} \times K_{\text {Skin }} \times C_{\text {Skin }}^{\text {DNA }}
$$

$$
\frac{d A_{\mathrm{GI}}^{3+}}{d t}=\mathrm{Q}_{\mathrm{GI}} \times\left(\mathrm{C}_{a}^{3+}-\frac{\mathrm{C}_{\mathrm{GI}}^{3+}}{\mathrm{P}_{\mathrm{GI}}^{3+}}\right)-\mathrm{Q}_{\mathrm{GI}} \times\left(\frac{\mathrm{C}_{\mathrm{GI}}^{3+}}{\mathrm{P}_{\mathrm{GI}}^{3+}}-\frac{\mathrm{C}_{\mathrm{Liver}}^{3+}}{\mathrm{P}_{\mathrm{Liver}}^{3+}}\right)+\left(\mathrm{K}_{1} \times \mathrm{C}_{\mathrm{GI}}^{5+}-\mathrm{K}_{2} \times \mathrm{C}_{\mathrm{GI}}^{3+}\right) \times \mathrm{V}_{\mathrm{GI}}-\mathrm{W}_{\text {day }} \times \mathrm{K}_{\mathrm{GI}} \times \mathrm{C}_{\mathrm{GI}}^{3+}+\mathrm{K}_{\text {uptake }}^{3+}
$$

$$
\frac{d A_{\mathrm{GI}}^{5+}}{d t}=\mathrm{Q}_{\mathrm{GI}} \times\left(\mathrm{C}_{a}^{5+}-\frac{\mathrm{C}_{\mathrm{GI}}^{5+}}{\mathrm{P}_{\mathrm{GI}}^{5+}}\right)-\mathrm{Q}_{\mathrm{GI}} \times\left(\frac{\mathrm{C}_{\mathrm{GI}}^{5+}}{\mathrm{P}_{\mathrm{GI}}^{5+}}-\frac{\mathrm{C}_{\mathrm{Liver}}^{5+}}{\mathrm{P}_{\mathrm{Liver}}^{5+}}\right)-\left(\mathrm{K}_{1} \times \mathrm{C}_{\mathrm{GI}}^{5+}-\mathrm{K}_{2} \times \mathrm{C}_{\mathrm{GI}}^{3+}\right) \times \mathrm{V}_{\mathrm{GI}}-\mathrm{W}_{\text {day }} \times \mathrm{K}_{\mathrm{GI}} \times \mathrm{C}_{\mathrm{GI}}^{3+}+\mathrm{K}_{\text {uptake }}^{5+}
$$

$$
\frac{d A_{\mathrm{GI}}^{\mathrm{MMA}}}{d t}=\mathrm{Q}_{\mathrm{GI}} \times\left(C_{a}^{\mathrm{MMA}}-\frac{C_{\mathrm{GI}}^{\mathrm{MMA}}}{\mathrm{P}_{\mathrm{GI}}^{\mathrm{MMA}}}\right)-\mathrm{Q}_{\mathrm{GI}} \times\left(\frac{C_{\mathrm{GI}}^{\mathrm{MMA}}}{\mathrm{P}_{\mathrm{GI}}^{\mathrm{MMA}}}-\frac{C_{\mathrm{Liver}}^{\mathrm{MMA}}}{\mathrm{P}_{\mathrm{Liver}}^{\mathrm{MMA}}}\right)-\mathrm{W}_{\text {day }} \times \mathrm{K}_{\mathrm{GI}} \times \mathrm{C}_{\mathrm{GI}}^{\mathrm{MMA}}
$$

$$
\frac{d A_{\mathrm{GI}}^{\mathrm{DMA}}}{d t}=\mathrm{Q}_{\mathrm{GI}} \times\left(C_{a}^{\mathrm{DMA}}-\frac{C_{\mathrm{GI}}^{\mathrm{DMA}}}{\mathrm{P}_{\mathrm{GI}}^{\mathrm{DMA}}}\right)-\mathrm{Q}_{\mathrm{GI}} \times\left(\frac{C_{\mathrm{GI}}^{\mathrm{DMA}}}{\mathrm{P}_{\mathrm{GI}}^{\mathrm{DMA}}}-\frac{C_{\mathrm{Liver}}^{\mathrm{DMA}}}{\mathrm{P}_{\mathrm{Liver}}^{\mathrm{DMA}}}\right)-\mathrm{W}_{\text {day }} \times \mathrm{K}_{\mathrm{GI}} \times \mathrm{C}_{\mathrm{GI}}^{\mathrm{DMA}}
$$

$$
\begin{aligned}
& \frac{d A_{\text {Liver }}^{3+}}{d t}=\mathrm{Q}_{\text {Liver }} \times\left(\mathrm{C}_{a}^{3+}-\frac{\mathrm{C}_{\text {Liver }}^{3+}}{\mathrm{P}_{\text {Liver }}^{3+}}\right)+\mathrm{Q}_{\mathrm{GI}} \times\left(\frac{\mathrm{C}_{\mathrm{GI}}^{3+}}{\mathrm{P}_{\mathrm{GI}}^{3+}}-\frac{\mathrm{C}_{\text {Liver }}^{3+}}{\mathrm{P}_{\text {Liver }}^{3+}}\right)-\left(\mathrm{K}_{1} \times \mathrm{C}_{\text {Liver }}^{5+}-\mathrm{K}_{2} \times \mathrm{C}_{\text {Liver }}^{3+}\right)
\end{aligned}
$$

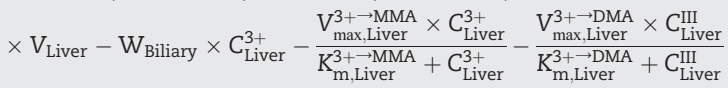

$$
\frac{d A_{\text {Liver }}^{5+}}{d t}=\mathrm{Q}_{\text {Liver }} \times\left(\mathrm{C}_{a}^{5+}-\frac{\mathrm{C}_{\text {Liver }}^{5+}}{\mathrm{P}_{\text {Liver }}^{5+}}\right)+\mathrm{Q}_{\mathrm{GI}} \times\left(\frac{\mathrm{C}_{\mathrm{GI}}^{5+}}{\mathrm{P}_{\mathrm{GI}}^{5+}}-\frac{\mathrm{C}_{\mathrm{Liver}}^{5+}}{\mathrm{P}_{\text {Liver }}^{5+}}\right)-\left(\mathrm{K}_{1} \times \mathrm{C}_{\text {Liver }}^{5+}-\mathrm{K}_{2} \times \mathrm{C}_{\text {Liver }}^{3+}\right) \times \mathrm{V}_{\mathrm{Liver}}-\mathrm{W}_{\text {Biliary }} \times \mathrm{C}_{\text {Liver }}^{5+}
$$

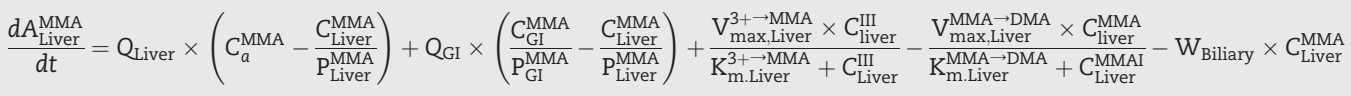

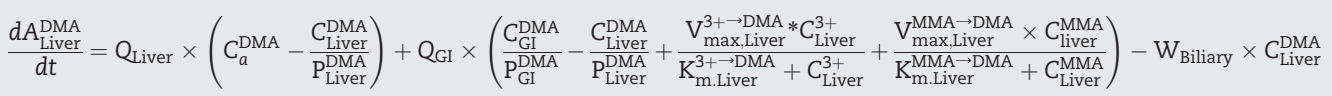

$$
\frac{d A_{\text {Muscle }}^{3+}}{d t}=Q_{\text {Muscle }} \times\left(C_{a}^{3+}-\frac{C_{\text {Muscle }}^{3+}}{P_{\text {Muscle }}^{3+}}\right)+\left(K_{1} \times C_{\text {Muscle }}^{5+}-K_{2} \times C_{\text {Muscle }}^{5+}\right) \times V_{\text {Muscle }}
$$

$$
\frac{d A_{\text {Muscle }}^{5+}}{d t}=Q_{\text {Muscle }} \times\left(C_{a}^{5+}-\frac{C_{\text {Muscle }}^{5+}}{P_{\text {Muscle }}^{5+}}\right)-\left(\mathrm{K}_{1} \times C_{\text {Muscle }}^{5+}-K_{2} \times C_{\text {Muscle }}^{3+}\right) \times V_{\text {Muscle }}
$$

$$
\begin{aligned}
& \frac{d A_{\text {Muscle }}^{\text {AMA }}}{d t}=Q_{\text {Muscle }} \times\left(C_{a}^{\text {MiA }}-\frac{C_{\text {Muscle }}^{\text {MaMA }}}{P_{\text {Muscle }}^{\text {MaMA }}}\right) \\
& \frac{d A_{\text {Muscle }}^{\text {DNA }}}{d t}=Q_{\text {Muscle }} \times\left(C_{a}^{\text {MA }}-\frac{C_{\text {Muscle }}^{\text {DuMA }}}{P_{\text {Muscle }}^{\text {Dis }}}\right)
\end{aligned}
$$

$$
\frac{d A_{\text {Fat }}^{3+}}{d t}=Q_{\text {Fat }} \times\left(C_{a}^{3+}-\frac{C_{\text {Fat }}^{3+}}{P_{\text {Fat }}^{3+}}\right)+\left(K_{1} \times C_{\text {Fat }}^{5+}-K_{2} \times C_{\text {Fat }}^{3+}\right) \times V_{\text {Fat }}
$$

(continued on next page) 


\section{Appendix A (continued)}

Fat

As(V)

$$
\frac{d A_{\text {Fat }}^{5+}}{d t}=Q_{\text {Fat }} \times\left(C_{a}^{5+}-\frac{C_{\text {Fat }}^{5+}}{P_{\text {Fat }}^{5+}}\right)-\left(K_{1} \times C_{\text {Fat }}^{5+}-K_{2} \times C_{\text {Fat }}^{3+}\right) \times V_{\text {Fat }}
$$

MMA

$$
\frac{d A_{\mathrm{Fat}}^{\mathrm{MMA}}}{d \mathrm{t}}=\mathrm{Q}_{\mathrm{Fat}} \times\left(C_{a}^{\mathrm{MMA}}-\frac{C_{\mathrm{Fat}}^{\mathrm{MMA}}}{P_{\mathrm{Fat}}^{\mathrm{MMA}}}\right)
$$

DMA

$$
\frac{d A_{\mathrm{Fat}}^{\mathrm{DMA}}}{d t}=Q_{\mathrm{Fat}} \times\left(C_{a}^{\mathrm{DMA}}-\frac{C_{\mathrm{Fat}}^{\mathrm{DMA}}}{P_{\mathrm{Fat}}^{\mathrm{DMA}}}\right)
$$

Blood

As(III)

$$
\frac{d A_{a}^{3+}}{d t}=\left(\sum_{i=1}^{8} \mathrm{Q}_{i} \times \frac{\mathrm{C}_{i}^{3+}}{\mathrm{P}_{\mathrm{i}}^{3+}}-\sum_{\mathrm{i}=1}^{8} \mathrm{Q}_{\mathrm{i}} \times \mathrm{C}_{a}^{3+}\right)+\left(\mathrm{K}_{1} \times \mathrm{C}_{a}^{5+}-\mathrm{K}_{2} \times \mathrm{C}_{a}^{3+}\right) \times \mathrm{V}_{a}
$$

As(V)

$$
\frac{d A_{a}^{5+}}{d t}=\left(\sum_{i=1}^{8} Q_{i} \times \frac{C_{i}^{5+}}{P_{i}^{5+}}-\sum_{i=1}^{8} Q_{i} \times C_{a}^{5+}\right)-\left(K_{1} \times C_{a}^{5+}-K_{2} \times C_{a}^{3+}\right) \times V_{a}
$$

MMA

$$
\frac{d A_{a}^{\mathrm{MMA}}}{d \mathrm{t}}=\left(\sum_{i=1}^{8} \mathrm{Q}_{\mathrm{i}} \times \frac{\mathrm{C}_{i}^{\mathrm{MMA}}}{\mathrm{P}_{\mathrm{i}}^{\mathrm{MMA}}}-\sum_{i=1}^{8} \mathrm{Q}_{i} \times \mathrm{C}_{a}^{\mathrm{MMA}}\right)
$$

DMA

$$
\frac{d A_{a}^{\mathrm{DMA}}}{d \mathrm{t}}=\left(\sum_{i=1}^{8} \mathrm{Q}_{i} \times \frac{\mathrm{C}_{i}^{\mathrm{DMA}}}{\mathrm{P}_{\mathrm{i}}^{\mathrm{DMA}}}-\sum_{i=1}^{8} \mathrm{Q}_{i} \times \mathrm{C}_{a}^{\mathrm{DMA}}\right)
$$

Abbreviations and parameter symbols: $A_{i}^{j}$ : dose of arsenic species $j$ in organ/tissue $i$ ( $\mu$ mol), $C_{i}^{j}$ : concentration of arsenic species $j$ in organ/ tissue $i(\mu \mathrm{mol} / \mathrm{L}), \mathrm{K}_{m, i}^{j \rightarrow}{ }^{k}$ : Michaelis-Menten constant for arsenic species $j$ methylated to $k$ in organ/tissue $i(\mu \mathrm{mol} / \mathrm{L})$, $\mathrm{P}_{i}^{j}$ : Tissue/blood partition coefficient of arsenic species $j$ in tissue, $Q_{i}$ : blood flow in organ/tissue $i(L / h), V_{i}$ : volume of organ/tissue $i(L), V_{\text {max, }}^{j \rightarrow k}$ : maximum reaction rate for arsenic species $j$ methylated to $k$ in organ/tissue $i(\mu \mathrm{mol} / \mathrm{h}), \mathrm{W}_{\text {Biliary}}$ : bile elimination amount (L), $\mathrm{W}_{\text {day }}$ : human daily drinking water amount (L/h), $\mathrm{W}_{i}$ : percentage of the mass of organ $i$ in body weight (\%).

\section{Appendix B. Input parameters used in the PBPK model}

\section{Table B1 - PBPK input parameters used for four age groups}

Parameters

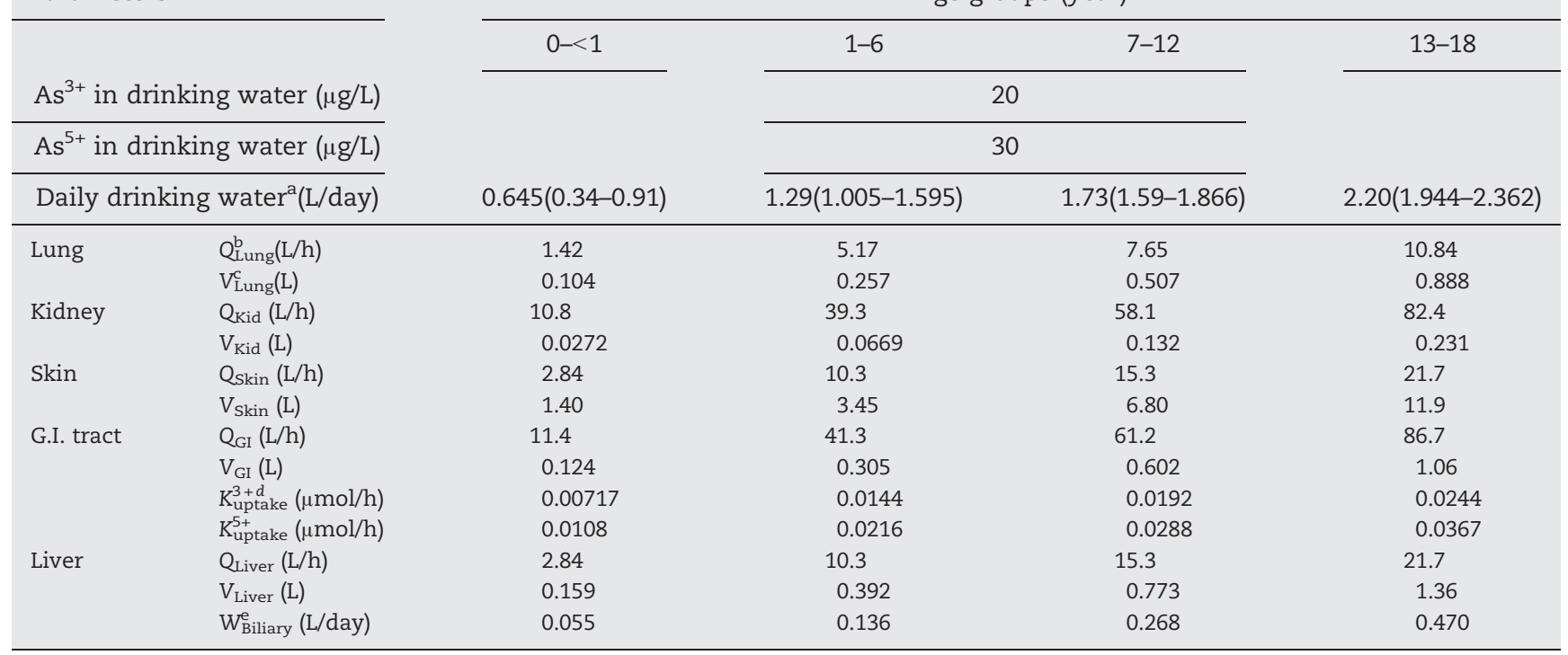




\section{Table B1 (continued)}

\section{Parameters}

$\longrightarrow$

\begin{tabular}{c}
$\mathrm{As}^{3+}$ in drinking water $(\mu \mathrm{g} / \mathrm{L})$ \\
\hline $\mathrm{As}^{5+}$ in drinking water $(\mu \mathrm{g} / \mathrm{L})$ \\
\hline Daily drinking water $(\mathrm{L} /$ day $)$
\end{tabular}

$\begin{array}{ll}\text { Muscle } & \text { Q }_{\text {Muscle }}(\mathrm{L} / \mathrm{h}) \\ \text { Fat } & \mathrm{V}_{\text {Muscle }}(\mathrm{L}) \\ & \mathrm{Q}_{\text {Fat }}(\mathrm{L} / \mathrm{h}) \\ \text { Blood } & \mathrm{V}_{\text {Fat }}(\mathrm{L}) \\ & \mathrm{V}_{a}^{f}(\mathrm{~L})\end{array}$

\begin{tabular}{|c|c|c|c|}
\hline \multicolumn{4}{|c|}{ Age groups (year) } \\
\hline $0-<1$ & $1-6$ & $7-12$ & $13-18$ \\
\hline & \multicolumn{2}{|c|}{20} & \\
\hline & \multicolumn{2}{|c|}{30} & \\
\hline $0.645(0.34-0.91)$ & $1.29(1.005-1.595)$ & $1.73(1.59-1.866)$ & $2.20(1.944-2.362)$ \\
\hline 9.66 & 35.1 & 52.0 & 73.7 \\
\hline 2.48 & 6.10 & 12.0 & 21.1 \\
\hline 2.84 & 10.3 & 15.3 & 21.7 \\
\hline 1.30 & 3.19 & 6.30 & 11.0 \\
\hline 0.489 & 1.20 & 2.37 & 4.16 \\
\hline
\end{tabular}

a Daily drinking water (L/day) was assumed that 0.1 (1/kg-day), $1+(\mathrm{BW}-10) \times 0.05$ (l/kg-day), $1.5+(\mathrm{BW}-20) \times 0.02(\mathrm{l} / \mathrm{kg}$-day) for 3-10 kg, 10-20 kg, $>20 \mathrm{~kg}$, respectively, which was adopted from Wong (2001). ${ }^{b} Q_{i}=F_{i} \times Q_{T}\left(F_{i}\right.$ : blood flow fraction; $Q_{T}$ : cardiac output rate) (Price et al., 2003). ${ }^{c} V_{i}(L)=$ BW $(\mathrm{kg}) \times W_{i} / D_{i}(\mathrm{~kg} / \mathrm{L})\left(V_{i}\right.$ : volume of organ $i$; BW: body weight; $W_{i}$ : percentage of body weight; $D_{i}:$ density of organ $\left.i\right)$.

$\mathrm{d}_{K_{\text {uptake }}}(\mu \mathrm{mol} / \mathrm{h})=$ as in drinking water $(\mu \mathrm{g} / \mathrm{L}) \times$ daily drinking water $(\mathrm{L} /$ day $) / 74.9216$ (As $\left.=74.9216\right)$.

${ }^{e}$ We assumed that $\mathrm{W}_{\text {Biliary-Children }}=\mathrm{W}_{\text {Biliary-Adult }} \times \mathrm{BW}_{\text {Children }} / \mathrm{BW}_{\text {Adult }}$.

${ }^{f} V_{a}=B W_{\text {Children }} \times 0.08 / D_{a}$ (Haddad et al., 2001).

\section{Table B2 - Metabolic rate constants for arsenic in humans}

Metabolic rate constants for arsenic in humans

\begin{tabular}{|c|c|c|c|c|c|c|}
\hline \multicolumn{3}{|l|}{ Oxidation/reduction ${ }^{a}$} & \multicolumn{4}{|l|}{ First order } \\
\hline Reduction (1/h) & & & 1.37 & & & \\
\hline Oxidation $(1 / \mathrm{h})$ & & & 1.83 & & & \\
\hline Methylation ${ }^{\mathrm{b}}$ & & & & & & \\
\hline Age groups(year) & $\mathrm{As}^{3+} \rightarrow \mathrm{MMA}$ & $\mathrm{As}^{3+} \rightarrow \mathrm{DMA}$ & $0-<1$ & $\begin{array}{l}1-6 \\
\mathrm{MMA} \rightarrow \mathrm{DMA}\end{array}$ & $7-12$ & $13-18$ \\
\hline Liver & & & & & & \\
\hline $\mathrm{V}_{\max }(\mu \mathrm{mol} / \mathrm{h})$ & 11.25 & 22.25 & $\begin{array}{l}7.44 \\
(6.08-8.72)\end{array}$ & $\begin{array}{l}14.30 \\
(13.83-14.65)\end{array}$ & $\begin{array}{l}13.06 \\
(10.61-14.87)\end{array}$ & $\begin{array}{l}5.58 \\
(5.15-6.51)\end{array}$ \\
\hline $\begin{array}{c}\mathrm{K}_{m}(\mu \mathrm{mol} / \mathrm{L}) \\
\text { Kidney }\end{array}$ & 100 & 100 & & & & \\
\hline $\mathrm{V}_{\max }(\mu \mathrm{mol} / \mathrm{h})$ & 7.5 & 10.02 & $\begin{array}{l}2.32 \\
(1.90-2.72)\end{array}$ & $\begin{array}{l}4.41 \\
(4.26-4.52)\end{array}$ & $\begin{array}{l}4.08 \\
(3.31-4.64)\end{array}$ & $\begin{array}{l}1.74 \\
(1.61-2.03)\end{array}$ \\
\hline $\mathrm{K}_{m}(\mu \mathrm{mol} / \mathrm{L})$ & 100 & 100 & & & & \\
\hline
\end{tabular}

${ }^{\mathrm{a} A d a p t e d ~ f r o m ~ Y u ~(1998) . ~}{ }^{\mathrm{b}}$ Adapted from Mann (1996a).

\section{Table B3 - Partition coefficients, blood flow fraction, and tissue density used in the PBPK model}

\begin{tabular}{|c|c|c|c|c|c|c|c|c|}
\hline \multirow[t]{2}{*}{ Tissue } & \multirow{2}{*}{$\begin{array}{l}\text { Blood } \\
\text { flow } \\
\text { fraction } \\
\left(F_{\mathrm{i}}\right)(\%)^{\mathrm{a}}\end{array}$} & \multirow{2}{*}{$\begin{array}{c}\% \text { of } \\
\text { body } \\
\text { weight } \\
\left(\mathrm{W}_{\mathrm{i}}\right) \\
(\%)^{\mathrm{a}}\end{array}$} & \multirow{2}{*}{$\begin{array}{c}\text { Density } \\
\left(D_{\mathrm{i}}\right) \\
\left(\mathrm{kg} \mathrm{L}^{-1}\right)^{\mathrm{a}}\end{array}$} & \multirow{2}{*}{$\begin{array}{c}\% \text { of total } \\
\text { water } \\
\text { elimination } \\
\text { amount } \\
(\%)^{b}\end{array}$} & \multicolumn{4}{|c|}{ Species-specific tissue/blood partition coefficien } \\
\hline & & & & & As(III) & $\mathrm{As}(\mathrm{V})$ & $\mathrm{MMA}(\mathrm{V})$ & $\mathrm{DMA}(\mathrm{V})$ \\
\hline Lung & 2.5 & 1.7 & 1.05 & 12 & 4.15 & 4.15 & 1.8 & 2.075 \\
\hline Kidneys & 19 & 4.4 & 1.05 & 60 & 4.15 & 4.15 & 1.8 & 2.075 \\
\hline Skin & 5 & 20 & 1.05 & 20 & 2.5 & 2.5 & 1.25 & 1.25 \\
\hline GI tract & 20 & 2 & 1.04 & 8 & 2.8 & 2.8 & 1.2 & 1.4 \\
\hline Liver & 6.5 & 2.57 & 1.05 & & 5.3 & 5.3 & 2.35 & 2.65 \\
\hline Muscle & 17 & 40 & 1.04 & & 2.6 & 2.6 & 1.8 & 2.8 \\
\hline Fat & 27.5 & 21 & 0.92 & & 0.3 & 0.3 & 0.3 & 0.3 \\
\hline Total & & & & 100 & & & & \\
\hline
\end{tabular}




\section{R E F E R E N C E S}

Ahsan HA, Perrin M, Parvez F, Stute M, Zheng Y, Milton AH, et al. Associations between drinking water and urinary arsenic levels and skin lesions in Bangladesh. J Occup Environ Med 2000;42:1195-210.

ATSDR. Toxicological profile for arsenic (uptake). Agency for Toxic Substances and Disease Registry. Atlanta, GA: U.S. Public Health Service; 2000.

Bhattacharjee Y. Toxicology - a sluggish response to humanity's biggest mass poisoning. Science 2007;315:1659-61.

Brown KG. Assessing risk of inorganic arsenic in drinking water in the United States. Hum Ecol Risk Assess 1998;4:1061-70.

Caldwell BK, Smith WT, Lokuge K, Ranmuthugala G, Dear K, Milton $\mathrm{AH}$, et al. Access to drinking-water and arsenicosis in Bangladesh. J Health Popul Nutr 2006;24:336-45.

Chen CJ, Chen CL, Hsu LY, Chou WL, Lin YC, Tseng MP, et al. Biological gradient between long-term arsenic exposure and cancer in Taiwan. Toxicology 2001;164:17-8.

Chen YC, Su HJJ, Guo YLL, Hsueh YM, Smith TJ, Ryan LM, et al. Arsenic methylation and bladder cancer risk in Taiwan. Cancer Causes Control 2003a;14:303-10.

Chen YC, Su HJJ, Guo YLL, Hsueh YM, Smith TJ, Ryan LM, et al. Arsenic methylation and skin cancer risk in southwestern Taiwan. J Occup Environ Med 2003b;45:241-8.

Chen CJ, Hsu LI, Wang CH, Shih WL, Hsu YH, Tseng MP, et al. Biomarkers of exposure, effect, and susceptibility of arsenic-induced health hazards in Taiwan. Toxicol Appl Pharmacol 2005;206:198-206.

Chiou HY, Chiou ST, Hsu YH, Chou YL, Tseng CH, Wei ML, et al. Incidence of transitional cell carcinoma and arsenic in drinking water: a follow-up study of 8102 residents in an arseniasis-endmic area in northeastern Taiwan. Am J Epidemiol 2001;153:413-8.

Chiou JM, Wang SW, Chen CJ, Deng CR, Lin W, Tai TY. Arsenic ingestion and increased microvascular disease risk: observations from the southwestern arseniasis-endemic area in Taiwan. Int J Epidemiol 2005;34:936-43.

Chowdhury UK, Biswas BK, Chowdhury TR, Samanta S, Mandal BK, Quamruzzaman CB, et al. Groundwater arsenic contamination in Bangladesh and West Bengal, India. Environ Health Perspect 2000;108:393-7.

Chowdhury UK, Rahman MM, Sengupta MK, Lodh D, Chanda CR, Roy S, et al. Pattern of excretion of arsenic compounds [arsenite, arsenate, $\mathrm{MMA}(\mathrm{V}), \mathrm{DMA}(\mathrm{V})]$ in urine of children compared to adults from an arsenic exposed area in Bangladesh. J Environ Sci Health Part A-Toxic 2003:87-113.

Christensen ER, Nyholm N. Ecotoxicological assays with algaeWeibull dose-response curves. Environ Sci Technol 1984;18:713-8.

Cuzick J, Evans S, Gillman M, Price Evans DA. Medicinal arsenic and internal malignancies. Br J Cancer 1982;45:904-11.

Cuzick J, Harris R, Mortimer PS. Palmar keratoses and cancer of the bladder and lung. Lancet 1984;1:530-3.

Cuzick J, Sasieni P, Evans S. Ingested arsenic, keratoses, and bladder-cancer. Am J Epidemiol 1992;136:417-21.

Easterling MR, Styblo M, Evans MV, Kenyon EM. Pharmacokinetic modeling of arsenite uptake and metabolism in hepatocytes mechanistic insights and implications for further experiments. J Pharmacokinet Pharmacodyn 2002;29:207-34.

Evans MV, Eklund CR. A graphical application of sensitivity analysis for gas uptake experiments using chloroform as an example. Toxicology Methods 2001;11:285-97.

Gentry P, Covington T, Mann S, Shipp A, Yager J, Clewell HJ. Physiologically based pharmacokinetic modeling of arsenic in the mouse. J Toxicol Environ Health 2004;67:43-71.

Guha Mazumder DN, Haque R, Ghosh N, De BK, Santra A. Arsenic levels in drinking water and the prevalence of skin lesions in West Bengal, India. Int J Epidemiol 1998;27:871-7.
Haddad S, Restieri C, Krishnan K. Characterization of age-related changes in body weights and organ weights from birth to adolescence in humans. J Toxicol Environ Health Part A 2001;64:453-64.

Haque R, Guha Mazumder DN, Samanta S, Ghosh N, Kalman D, Smith MM, Mitra S, et al. Arsenic in drinking water and skin lesions: dose-response data from West Bengal, India. Epidemiol 2003;14:174-82.

Hissink AM, Wormhoudt LW, Sherratt PJ, Hayes JD, Commandeur JNM, Vermeulen NPE, et al. A physiologically-based pharmacokinetic (PB-PK) model for ethylene dibromide: relevance of extrahepatic metabolism. Food Chem Toxicol 2000;38:707-16.

Hsueh YM, Ko YF, Huang YK, Chen HW, Chiou HY, Yang MH, et al. Determinants of inorganic arsenic methylation capability among residents of the Lanyang Basin, Taiwan: arsenic and selenium exposure and alcohol consumption. Toxicol Lett 2003;137:49-63.

Huang YC. Introduction to anatomy and physiology. 3rd ed. Taipei, Taiwan: Hweihua Publishing Company; 2000. p. 589-609. [Chap 14].

IARC. Some drinking-water disinfectants and Contaminants, including arsenic, vol. 84. Lyon: International Agency for Research on Cancer; 2004.

Kenyon EM, Del Razo L, Hughes MF. Comparative tissue distribution and urinary excretion of inorganic arsenic (iAs) and its methylated metabolites in mice following oral administration of arsenate (AsV) and arsenite (AsIII). Toxicol Sci 2003;72:148-148 Suppl.

Kitchin KT, Del Razo LM, Brown JL, Anderson WL, Kenyon M. An integrate pharmacokinetic and pharmacodynamic study of arsenic action. 1. Heme. 1. Heme oxygenase induction in rats. Teratog Carcinog Mutagen 1999;19:385-402.

Kodell RL, Chen JJ, Delongchamp RR, Young JF. Hierarchical models for probabilistic dose-response assessment. Regul Toxicol Pharmacol 2006;45:265-72.

Lamm SH, Engel A, Penn CA, Chen R, Feinleib M. Arsenic cancer risk confounder in southwest Taiwan data set. Environ Health Perspect 2006;114:1077-82.

Mann S, Droz PO, Vahter M. A physiologically based pharmacokinetic model for arsenic exposure. I. Development in hamsters and rabbits. Toxicol Appl Pharmacol 1996a;137:8-22.

Mann S, Droz PO, Vahter M. A physiologically based pharmacokinetic model for arsenic exposure. II. Validation and application in humans. Toxicol Appl Pharmacol 1996b;140:471-86.

McCarty KM, Houseman EA, Quamruzzman Q Rahman M, Mahiuddin G, Smith T, et al. The impact of diet and betel nut use on skin lesions associated with drinking-water arsenic in Pabna, Bangladesh. Environ Health Perspect 2006;114:334-40.

McCarty KM, Chen YC, Quamruzzaman Q Rahman M, Mahiuddin G, Hsueh YM, et al. Arsenic methylation, GSTT1, GSTM1, GSTM1, GSTP1 polymorphisms, and skin lesions. Environ Health Perspect 2007;115:341-5.

McDonald C, Hoque R, Huda N, Cherry N. Prevalence of arsenic-related skin lesions in 53 Widely-scattered villages of Bangladesh: an ecological survey. J Heatlh Popul Nutr 2006;24:228-35.

Morales KH, Ryan L, Kuo TL, Wu MM, Chen CJ. Risk of internal cancers from arsenic in drinking water. Environ Health Perspect 2000;108:655-61.

National Research Council. Arsenic in drinking water. Washington, DC: National Academy Press; 2001a.

NRC. Arsenic in drinking water: update. Washington, D.C.: National Academy Press; 2001b.

Navas-Acien A, Sharrett AR, Silbergeld EK, Schwartz BS, Nachman KE, Burke TA, Guallar E. Arsenic exposure and cardiovascular disease: a systematic review of the epidemiologic evidence. Am J Epidemiol 2005;162:1037-49.

Price K, Haddad S, Krishnan K. Physiological modeling of age-specific changes in the pharmacokinetics of organic chemicals in children. J Toxicol Environ Health Part A 2003;66:417-33. 
Rahman M, Vahter M, Sohel N, Yunus M, Wahed MA, Streatifeld $\mathrm{PK}$, et al. Arsenic exposure and age- and sex-specific risk for skin lesions: a population-based case-referent study in Bangladesh. Environ Health Perspect 2006a;114:1847-52.

Rahman M, Vahter M, Sohel N, Yunus M, Wahed MA, Streatifeld PK, et al. Prevalence of arsenic exposure and skin lesion. Skin lesion. A population based survey in Matlab, Bangladesh. Environ Health Perspect 2006b;60:242-8.

Smith AH, Sharp DS. A standardized benchmark approach to the use of cancer epidemiology data for risk assessment. Toxicol Ind Health 1985;1:205-12.

Smith AH, Lingas EO, Rahman M. Contamination of drinking-water by arsenic in Bangladesh: a public health emergency. Bull World Health Organ 2000;78:1093-103.

Smith DR, Guo YLL, Lee YL, Hsieh FS, Chang SJ, Shue HM. Prevalence of skin disease among nursing home staff in southern Taiwan. Ind Health 2002;40:54-8.

Sun G, Xu Y, Li X, Jin Y, Li B, Sun X. Urinary arsenic metabolites in children and adults exposed to arsenic in drinking water in inner Mongolia, China. Environ Health Perspect 2007;115:648-52.

ten Berge WF. Kaplan-Meier tumor probability as a starting point for dose-response modeling provides accurate lifetime risk estimates from rodent carcinogenicity studies. Ann NY Acad Sci 1999;895:112-24.

Tondel M, Rahman M, Magnuson A, Chowdhury IA, Faruquee MH, Ahmad SA. The relationship of arsenic levels in drinking water and the prevalence rate of skin lesions in Bangladesh. Environ Health Perspect 1999;107:727-9.

Tseng WP, Chu HM, How SW, Fong JM, Lin CS, Yeh S. Prevalence of skin cancer in an endemic area of chronic arsenicism in Taiwan. Prevalence of skin cancer in chronic arsenism. J Natl Cancer Inst 1968;40:453-63.

Tseng WP. Effects and dose-response relationships of skin cancer and blackfoot disease with arsenic. Environ Health Perspect 1977;19:109-19.

USEPA. Risk-based concentration table, January-June 1996. USEPA Region 3, Philadelphia, PA; 1996.

USEPA. Guidelines for ecological risk assessment. Washington DC: US Environmental Protection Agency; 1998.

USEPA. Preliminary evaluation of the non-dietary hazard and exposure to children from contact with chromated copper arsenate treated wood playground structures and contaminated soil. Washington DC: US Environmental Protection Agency; 2001.

USEPA. Arsenic in Drinking Water. Washington DC: US Environmental Protection Agency; 2002.

Valenzuela OL, Borja-Aburto VH, Garcia-Vargas GG, Cruz-Gonzalez MB, Garcia-Montalvo EA, Calderon-Aranda ES, et al. Urinary trivalent methylated arsenic species in a population chronically exposed to inorganic arsenic. Environ Health Perspect 2005;113:250-4.

WHO/IPCS. Environmental Health Criteria 224, Arsenic and Arsenic Compounds. second edition. Geneva: World Health Organization; 2001.

Wong DL. Whaley \& Wong's Essentials of Pediatric Nursing. 6th ed. St. Louis: Mosby; 2001.

Yang CY, Chang CC, Tsai SS, Chuang HY, Chuang HY, Ho CK, et al. Arsenic in drinking water and adverse pregnancy outcome in an arseniasis-endemic area in northeastern Taiwan. Environ Res 2003a;91:29-34.

Yang CY, Chuang HY, Ho CK, Wu TN, Wu MTF. Arsenic in drinking water and adverse pregnancy outcome in an arseniasis-endemic area in Northeastern Taiwan. Epidemiology 2003b;14 S127-S127.

Yang CY, Chiu HF, Chang CC, Ho SC, Wu TN. Bladder cancer mortality reduction after installation of a tap-water supply system in an arsenious-endemic area in southwestern Taiwan. Environ Res 2005;98:127-32.

Yu D. Uncertainties in a pharmacokinetic modeling for inorganic arsenic. J Environ Sci Health Part A-Toxic 1998:1369-90.

Yu D. A pharmacokinetic modeling of inorganic arsenic: a short-term oral exposure model for humans. Chemosphere 1999a;39:2737-47.

Yu D. A physiologically based pharmacokinetic model of inorganic arsenic. Regul. Toxicol Pharmacol 1999b;29:128-41.

Yu D, Kim JK. A physiologically based assessment of human exposure to radon released from groundwater. Chemosphere 2004;54:639-45.

Yu WH, Harvey CM, Harvey CF. Arsenic in groundwater in Bangladesh: a geostatistical and epidemiological framework for evaluating health effects and potential remedies. Water Resour Res 2003;39:1-17. 